\title{
Synthesis and Characterization of Alkyd Resin from Albizia lebbeck (frywood) seeds
}

\author{
Ezugwu MU ${ }^{1}$, Obidiegwu MU ${ }^{1},{\text { Ezugwu } \mathrm{CH}^{2,3}, \mathrm{Ipav} \mathrm{SS}^{3} \text {, Dasofunjo } \mathrm{K}^{2,4} \text { and Berinyuy E.B }}^{5}$ \\ ${ }^{1}$ Department of Polymer and Textile Engineering, Federal University of Technology, Owerri, Imo State \\ ${ }^{2}$ Department of Biochemistry, University of Nigeria, Nsukka, Nigeria \\ ${ }^{3}$ Department of Chemical Sciences, University of Mkar, Mkar, Benue State, Nigeria \\ ${ }^{2,4}$ Department of Medical Biochemistry, Cross River University of Technology, Okuku Campus \\ ${ }^{5}$ Faculty of Medicine and Biomedical Sciences, University of Yaounde 1, Cameroun, \\ *Authors for Correspondence: echikata@yahoo.com; martindinm@gmail.com
}

DOI: $10.31364 / \mathrm{SCIRJ} / \mathrm{v} 7.19 .2019 . P 0919703$

http://dx.doi.org/10.31364/SCIRJ/v7.i9.2019.P0919703

\begin{abstract}
Alkyd resin was synthesized from the Albizia lebbeck (frywood) seed oil (FWO) and the physico-chemical properties of both the oil and the consequent alkyd resin were studied. Fourier Transform Infra-red (FTIR) spectroscopy was used to investigate the functional groups present in the alkyd resin. MATLAB was used to generate model equations for the extent of reaction for the synthesis of the alkyd resin. The oil extracted from the plant's seeds has a percentage yield of $17.32 \% \mathrm{w} / \mathrm{w}$, exhibited yellow colour and was liquid at room temperature. Other physico-chemical properties of the oil such as density, specific gravity $\left(30^{\circ} \mathrm{C}\right)$, refractive index $\left(30^{\circ} \mathrm{C}\right)$, viscosity $\left(30^{\circ} \mathrm{C}\right)$, saponification value, iodine value, acid value, free fatty acids and peroxide value were determined to be $0.89 \mathrm{~g} / \mathrm{cm}^{3}, 0.84,1.48,27.064 \mathrm{~m}^{2} / \mathrm{S}, 207.22 \mathrm{mgKOH} / \mathrm{g}, 122.18 \mathrm{gI}_{2} / 100 \mathrm{~g}, 8.98 \mathrm{mgKOH} / \mathrm{g}, 4.52 \%$ and $10.00 \mathrm{mEq} / \mathrm{kg}$ respectively. The synthesized alkyd resin from frywood seed oil (FWOAR) was dark-brown in colour while that of the commercially prepared alkyd resin (CPAR) was colourless. Physico-chemical properties of FWOAR such as specific gravity $\left(30^{\circ} \mathrm{C}\right)$, viscosity $\left(30^{\circ} \mathrm{C}\right)$, saponification value, iodine value and acid value were investigated to be $47.58,36.50,361.85 \mathrm{mgKOH} / \mathrm{g}, 32.33 \mathrm{gI}_{2} / 100 \mathrm{~g}$ and $7.01 \mathrm{mgKOH} / \mathrm{g}$ respectively. These values, except that of saponification $(361.85 \mathrm{mgKOH} / \mathrm{g}$ vs $263.97 \mathrm{mgKOH} / \mathrm{g})$, were not significantly difference when compared to those of CPAR that were determined to be $47.40,32.34 \mathrm{~m}^{2} / \mathrm{S}, 263.97 \mathrm{mgKOH} / \mathrm{g}$, $48.22 \mathrm{gI}_{2} / 100 \mathrm{~g}$ and $6.31 \mathrm{mgKOH} / \mathrm{g}$ respectively. Variations in acid value $(\mathrm{AV})$, viscosity, extent of reaction $\left(\mathrm{R}_{\mathrm{e}}\right)$ and degree of polymerization $\left(D_{p}\right)$ of in-process alkyd sample with time were studied. Viscosity, $D_{p}$ and $R_{e}$ increased with time while AV decreased with time. The IR spectra of the test alkyd resin and the commercially prepared alkyd resin showed that the broad band shoulder around $3859.69 \mathrm{~cm}^{-1}$ and $3498.02 \mathrm{~cm}^{-1}$ were due to the $\mathrm{OH}$ stretch hydroxyl of the unsaturated fatty acid. The peak value within the range of $2930.93 \mathrm{~cm}^{-1}-2933.83 \mathrm{~cm}^{-1}$ observed in both alkyd resins corresponds to SCN and the peak height observed around $1727.31 \mathrm{~cm}^{-1}$ was due to $\mathrm{CO}$ stretch of unsaturated cyclic ester of monoglyceride. The presence of vinylidene compounds of unsaturated fatty acid of diglyceride and triglyceride were suggested in the peaks observed in both alkyds. From the performance tests, it was observed that the drying trend was faster in CPAR than FWOAR. CPAR showed higher resistant to water and acidic medium than FWOAR and both were poorly resistant to alkaline medium. Results so far obtained from this study suggest that the FWO and FWOAR exhibited good performance characteristics even when FWOAR was compared with the commercially produced alkyd resin and there are similar functional groups in the compounds observed in the absorbance of IR spectra.
\end{abstract}

Key words: Seed oil, Alkyd resin, physicochemical, Alcoholysis, Esterification, Polymerization.

\section{INTRODUCTION}

Alkyd resin is defined as the reaction product of an oil or fatty acid, polyol and polyacid (Malti, 1978). The inclusion of the fatty acid confers a tendency to form flexible coating. Alkyd resins are used in many solvent-based paint systems and are a type of polyester made from polyols, acids and vegetable oils. They are the dominant resin or "binder" in most commercial "oil-based" coatings. The original alkyds were compounds of glycerol and phthalic acid sold under the name Glyptal. Alkyd resins have acquired a good reputation because of their economy, availability of raw materials and ease of application (Mukhtar et al., 2007). They are to a greater extent biologically degradable polymers because of the oil and glycerol parts and they are ecofriendly compared to petroleum based polymers that constitutes environmental pollution and degradation. There are other unique properties of alkyd resins that make it an 
indispensible raw material in surface coating industry and they include: gloss and gloss retention, film flexibility and durability,good adhesion and ease of application under variable environmental conditions (Ogunniyi and Odetoye, 2008).

Albizia lebbeck is a species of Albizia, native to Indomalaya, New Guinea and Northern Australia and widely cultivated and naturalised in other tropical and subtropical regions. English names for it include lebbeck or lebbek plant, flea plant, frywood, koko and woman's tongues plant. The latter name is a play on the sound the seeds make as they rattle inside the pods (Brown, 1997). It is a plant growing to a height of $18-30 \mathrm{~m}$ tall with a trunk $50 \mathrm{~cm}$ to $1 \mathrm{~m}$ in diameter. The leaves are bipinnate, $7.5-15 \mathrm{~cm}$ long, with one to four pairs of pinnae, each pinna with 6-18 leaflets. The flowers are white, with numerous $2.5-3.8 \mathrm{~cm}$ long stamens, and very fragrant. The fruit is a pod $15-30 \mathrm{~cm}$ long and $2.5-5.0 \mathrm{~cm}$ broad, containing six to twelve seeds (Duke, 2008). Its uses include environmental management, forage, medicine and wood. It is cultivated as a shade plant in North and South America. In India and Pakistan, the plant is used to produce timber. Wood from Albizia lebbeck has a density of $0.55-0.66 \mathrm{~g} / \mathrm{cm}^{3}$ or higher. Even where it is not native, some indigenous herbivores are liable to utilize lebbeck as a food resource. For example, the greater rhea (Rhea americana) has been observed feeding on it in the cerrado of Brazil (Lowry et al., 1994; Ratsch, 2004).

Lebbek plant is used by some cultures to treat boils, cough, eye problems, flu, gingivitis, lung problems, pectoral problems and abdominal tumors. The bark is used medicinally to treat inflammation. Albizia lebbeck is also psychoactive. In ancient Tamil culture, the flowers of the lebbeck decorated as a crown were used to welcome victorious soldiers (Christiano et al., 2006; Barbosa, 2014). The seed oil is used for leprosy and the swelling powder. Indians use the flowers for spermatorrhea and it has astringent, rejuvenating and tonic action (Barbosa, 2014).
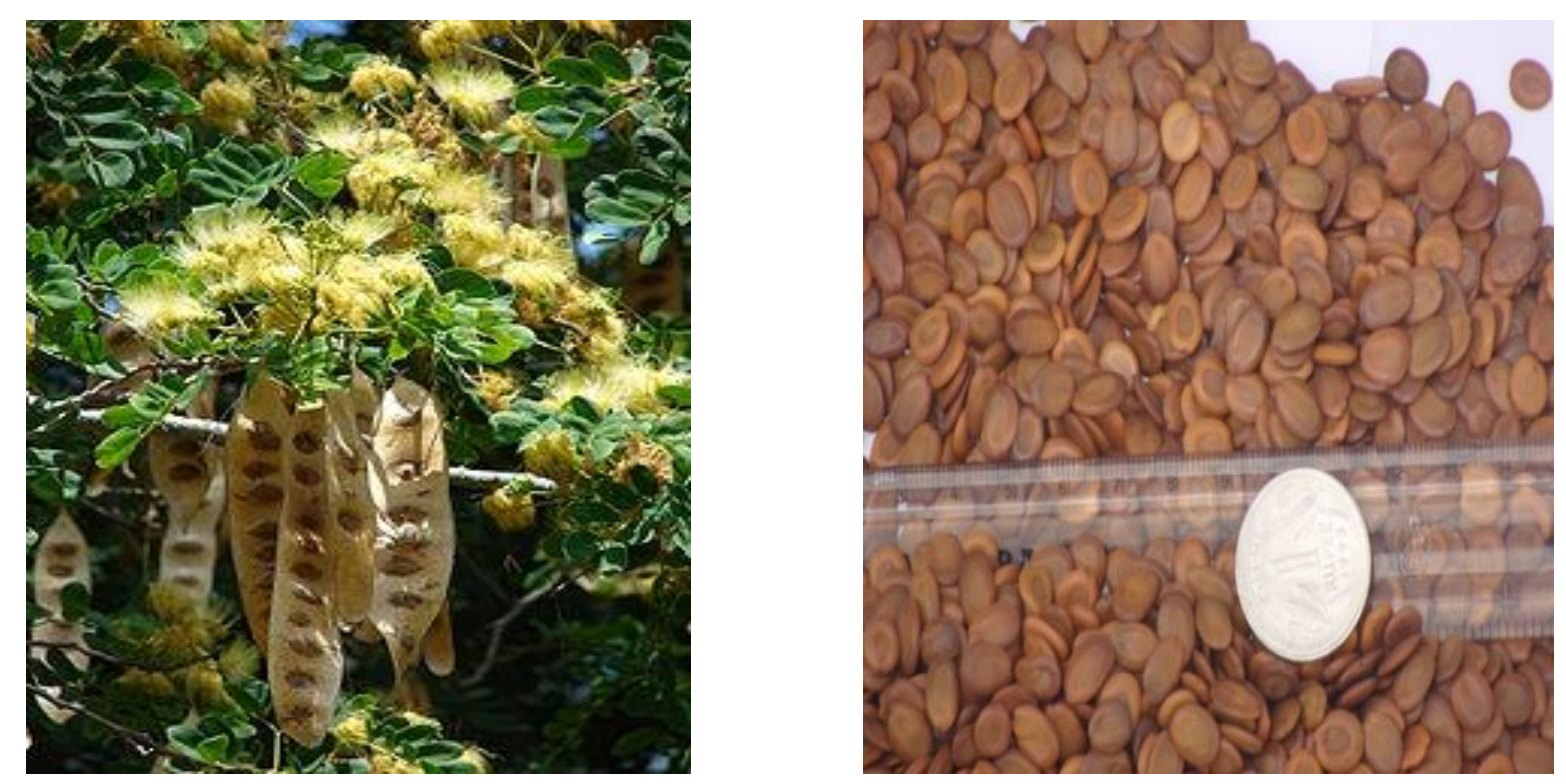

Figure 1: Fry wood plant (Albizia lebbeck) and frywood seeds (Lowry et al., 1994)

Acording to El-Hawary et al. (2011), GC/MS analysis of lipoidal matter of Albizia lebbeck showed the methyl esters of fatty acids ranged from 46.40 to $52.30 \%$ of which linoleic acid was discovered to be the major fatty acid in seed followed by palmitic acid and oleic acid for A. lebbeck and oleic acid and behenic acid for A. saman. Both oils contain slightly more than $30 \%$ saturated fatty acids with stearic, eicosanoic and tetracosanoic acids present as well as odd-numbered saturated fatty acids in minor amounts. In addition, beta-sitosterol was the major unsaponifiable component in seed. The fatty acid composition of the oils varied with C18:2 fatty acid; being the most dominant in the oil. Neutral lipids were the most abundant lipid class found in the oil while molecular species of the 
triacylglycerol with equivalent carbon chain number C40 was absent in the oil of Albizia lebbeck seed (Adewuyi and Oderinde, 2014).

Furthermore, for the first time, epoxy fatty acids are reported in the fatty acid profiles of Albizia seed oils. Coronaric acid (9,10epoxy-12(Z)-octadecenoic acid) is the major epoxy fatty acid at approximately 3-4\% of the fatty acid profiles with minor amounts of vernolic (12,13-epoxy-9(Z)-octadecenoic acid) and 9,10-epoxystearic acids also detected. The results are compared to previous literature on the fatty acid profiles of other Albizia seed oils. The coronaric acid content of Albizia resembles that of Acacia species with both genera belonging to the Fabaceae family. The mass spectrum of the pyridylcarbinol (picolinyl) ester of coronaric acid is reported (Knothe et al., 2014). Current literatures markedly lacked data and information about synthesis of alkyd resin from Albizia lebbeck seed oil.

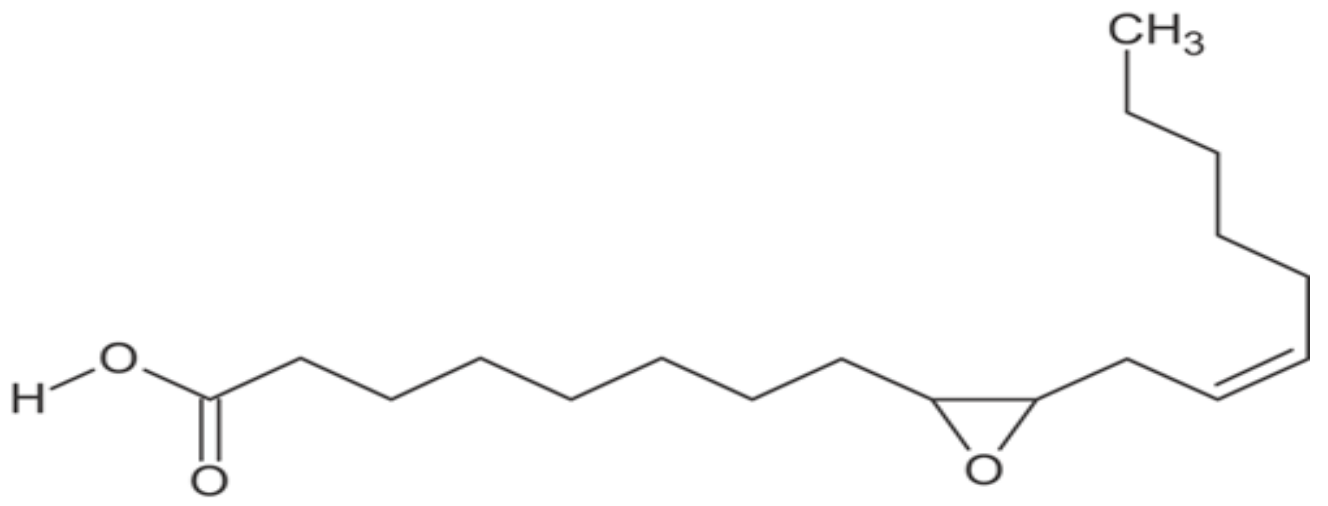

Figure 2: The coronaric acid of Albizia lebbeck and Albizia saman seed oils (Knothe et al., 2014)

\section{MATERIALS AND METHODS}

\section{Materials}

\section{Plant materials}

The seeds of Albizia lebbeck (frywood) were collected from Otukpo in Otukpo Local Government Area Benue State of Nigeria. The plant was authenticated at the Centre for Ethenomedicine and Drugs Development, a subsidiary of Bioresources Development and Conservation Program (BCDP) Nsukka, Enugu State.

\section{Chemicals}

N-Hexane, acetone, Iodine monochloride, glacial acetic acid, carbon tetrachloride, sodium thiosulphate, potassium Iodide, Wij's solution, phthalic anhydride, glycerol, $\mathrm{HCl}$ acid, Marble chips, Oxygen Scavenger and other chemicals (Nave and Dave, England) used in extraction, analysis, production and evaluation of the properties of the seed oil and the alkyd derivative of the plant were of analytical grade and were used as received without further purification.

\section{Instruments}

Instruments such as industrial blender, electronic weighing balance, desiccators, quick fit neck(pyrex), soxhlet extractor timble, reflux condenser, hot plate model no. 9005, retort stand, beakers, measuring cylinders, stoppers, watch glasses, stirrers, 3 neck round bottom flask $(500 \mathrm{ml})$, thermometer $\left(0^{\circ} \mathrm{C}-300^{\circ} \mathrm{C}\right)$, heating mantle model no. AM325013, kinematic viscometer, fume cupboard and FTIR-8400S Fourier transform infrared spectrophotometer were used in this study.

\section{Methods}

\section{Extraction of seed oil}


The seeds of frywood plant were sun-dried to a constant weight for about three (3) weeks and then subjected to temperatures of about $40^{\circ} \mathrm{C}-50^{\circ} \mathrm{C}$ for two (2) hours in an oven. The seeds $(2.5 \mathrm{~kg})$ were grinded using industrial grinding machine and then stored in desiccators for further study. The oil from the seeds was extracted using soxhlet extraction methods. The extraction process was done using N-hexane of boiling range $64^{\circ} \mathrm{C}-70^{\circ} \mathrm{C}$ as described by Esuoso and Odetokun (1995). The extracting solvent was evaporated leaving the concentrated oil sample for further analysis.

\section{Physico-chemical characterization of the seed oil}

\section{Determination of physical characterization of seed oil}

The colour of the oil sample was determined by observation using colour sensation of the human eyes. Specific gravity (SG) was determined at $30^{\circ} \mathrm{C}$ using Picometer. Viscosity was performed using a kinematic viscometer at $30^{\circ} \mathrm{C}$ and was measured in $\mathrm{m}^{2} / \mathrm{S}$

\section{Determination of oil yield}

The percentage yield of the seed oil extracted was determined by weighing the dried grinded seed powder and the concentrated oil and calculated by the formula shown below:

Percentage Yield $(\% \mathrm{w} / \mathrm{w})=\frac{\text { weight of concentrated oil }}{\text { weight of dry seed powder }} \times 100$

\section{Determination of density}

The density of the oil sample was determined by the method described below.

Procedure:

i. The mass of the empty measuring cylinder was determined using an electronic balance.

ii. A small amount of oil sample was poured directly into the measuring cylinder and weighed using the electronic balance.

iii. The volume of oil sample in the measuring cylinder was recorded.

The calculation is given as:

Density $\left(\mathrm{g} / \mathrm{cm}^{3}\right)=\frac{\left[\mathrm{M}_{2}-\mathrm{M}_{1}\right]}{\mathrm{V}}$

where,

$\mathrm{M}_{1}=$ Mass in grams of empty measuring cylinder

$\mathbf{M}_{2}=$ Mass in grams of empty measuring cylinder + mass in grams of oil

$\mathrm{V}=$ Volume of oil in $\mathrm{cm}^{3}$

\section{Determination of specific gravity}

The specific gravity (SG) of the oil sample was determined by the method described below:

A Picometer was rinsed with distilled water, followed by acetone and allowed to dry. The empty Picometer was weighed and recorded as $\mathrm{W}_{1}$. A known volume of water with the picometer was also weighed and recorded as $\mathrm{W}_{2}$. An equal volume of the oil sample with the picometer was weighed and recorded as $\mathrm{W}_{3}$. The $\mathrm{SG}$ was calculated using the equation below:

$\mathrm{SG}=\frac{\left\lfloor\mathrm{W}_{3}-\mathrm{W}_{1}\right\rfloor}{\left[\mathrm{W}_{2}-\mathrm{W}_{1}\right]}$

Determination of refractive index 
Refractive index of the oil was determined at $30^{\circ} \mathrm{C}$ using Abbe's refractometer. The machine was turned. The cell was rinsed with water, followed by acetone and allowed to dry by draining it. The oil sample was added into the cell and the reading taken respectively.

\section{Determination of viscosity}

Viscosity of the oil was determined at $30^{\circ} \mathrm{C}$ using a U-tube Viscometer. The Viscometer was rinsed with organic solvent (acetone) and allowed to dry. A small quantity of the oil sample was added from one end of the viscometer with micro pipette to fill the mark. At the release of each sample, a stop watch was put on and the time taken for the oil to flow from the point of origin to the calibrated mark was noted. The reading of the calibrated mark reached at an interval of time was taken and multiplied by a constant factor $\left(0.2483 \mathrm{~mm}^{2} / \mathrm{S}^{2}\right.$ or $\left.0.2483 \mathrm{~m}^{2} / \mathrm{S}\right)$ to obtain the sample's viscosity.

\section{Determination of iodine value}

Iodine value is used to determine the amount of unsaturation present in an oil sample. Iodine is only slowly absorbed by oil but is rapidly taken up by Wijs solution, which consists of a solution of iodine monochloride (ICl) in glacial acetic acid and carbon tetrachloride. The unsaturated bonds present takes up the iodine to saturate the double bonds and the remaining unabsorbed iodine is then titrated by means of sodium thiosulphate. The method of ASTM (1979) was used in determining the iodine value.

Reagents used:
i. Carbon tetrachloride $\left(\mathrm{CCl}_{4}\right)$, inert to Wijs solution
ii. $\quad 10 \%$ solution of Potassium Iodide (KI)
iii. $\quad 0.1 \mathrm{~N}$ Sodium thiosulphate $\left(\mathrm{Na}_{2} \mathrm{~S}_{2} \mathrm{O}_{3}\right)$
iv. Iodine trichloride $\left(\mathrm{ICl}_{3}\right)$
v. Glacial acetic acid
vi. Potassium dichromate
vii. Hydrochloric acid $(\mathrm{HCl})$ free from chlorine
viii. Freshly prepared soluble Starch solution ( $1 \mathrm{~g}$ of starch in $100 \mathrm{ml}$ of water)

Procedure:

a) $0.49 \mathrm{~g}$ of oil sample was dissolved in $15 \mathrm{ml} \mathrm{CCl}_{4}$ in a clean dry glass bottle with a fitting glass stopper.

b) $20 \mathrm{ml}$ of Wijs solution was added and sealed effectively by moisturing the stopper with a minimum quantity of $10 \% \mathrm{KI}$.

c) The bottle was allowed to stand for 30 minutes at a temperature of $15^{\circ} \mathrm{C}-20^{\circ} \mathrm{C}$ in a dark place.

d) After 30 minutes, $15 \mathrm{ml}$ of $10 \% \mathrm{KI}$ solution and $10 \mathrm{ml}$ of distilled water was added.

e) The solution was then titrated with $0.1 \mathrm{~N} \mathrm{Na}_{2} \mathrm{~S}_{2} \mathrm{O}_{3}$ solution using Starch as an indicator.

f) A blank experiment was also carried out using the same procedure without use of the sample.

The calculation is giving as:

Iodine Value $=\frac{12.69\left[\mathrm{~V}_{1}-\mathrm{V}_{2}\right]}{\mathrm{W}} \times 0.1$

where,

$\mathrm{V}_{1}=$ Volume (ml) of thiosulphate solution used in the blank

$\mathrm{V}_{2}=$ Volume $(\mathrm{ml})$ of thiosulphate solution used in the test

$\mathrm{W}=$ Weight $(\mathrm{g})$ of sample

Determination of saponification value 
The oil sample was completely saponified by heating with an excess of alcoholic potassium hydroxide $(\mathrm{KOH})$, the excess remaining being estimated by direct titration with standard acid (ASTM, 1979).

Reagents used:

I. $\quad 0.5 \mathrm{~N}$ alcoholic $\mathrm{KOH}$

II. $\quad 0.05 \mathrm{~N}$ aqueous $\mathrm{HCl}$

III. Neutral $1 \%$ alcoholic phenolpthalein solution

Procedure:

a) $0.74 \mathrm{~g}$ of oil sample was weighed directly into a flask using an electronic weighing balance.

b) $12.5 \mathrm{ml} 0.5 \mathrm{~N}$ alcoholic $\mathrm{KOH}$ solution was added using a Burette.

c) The flask was then fitted with an air condenser tube and heated to boiling temperature in a steam bath.

d) After slightly cooling the solution, $1 \mathrm{ml}$ of phenolpthalein indicator was added.

e) It was then titrated using $0.6667 \mathrm{~N} \mathrm{HCl}$ until it turned pink.

f) The burette reading was recorded.

g) A blank experiment using the same procedure without the sample was performed.

The calculation is given as:

Saponification Value $=\frac{56.1 \mathrm{~N}\left[\mathrm{~V}_{1}-\mathrm{V}_{2}\right]}{\mathrm{W}}$

where,

$\mathrm{N}=$ Normality of $\mathrm{HCl}$ acid used

$\mathrm{V}_{1}=$ Volume of Hydrochloric acid used in the blank.

$\mathrm{V}_{2}=$ Volume of Hydrochloric acid used in the test.

$\mathrm{W}=$ Weight of oil sample used.

\section{Determination of peroxide value:}

For peroxide value (PV), $1 \mathrm{~g}$ of the oil sample was weighed into a $200 \mathrm{ml}$ conical flask, then $25 \mathrm{ml}$ of 2:1 glacial acetic acid:chloroform solvent was added. This was followed by addition of $1 \mathrm{ml}$ of saturated $\mathrm{KI}$ and the mixture left in the dark for 1 minute. Next, $30 \mathrm{ml}$ of distilled water was added and the mixture titrated with $0.02 \mathrm{~N}$ thiosulphate solution using $5 \mathrm{ml}$ starch as indicator. A blank determination was similarly carried out (Pagout and Hautfenne, 1987). The PV was calculated from the equation:

$\mathrm{PV}=\frac{\left[100\left(\mathrm{~V}_{1}-\mathrm{V}_{2}\right) \mathrm{mg} / \mathrm{kg}\right]}{\mathrm{W}}$

where,

$\mathrm{W}=$ weight of oil sample

$\mathrm{V}_{1}=$ Volume $(\mathrm{ml})$ of thiosulphate used in test

$\mathrm{V}_{2}=$ Volume (ml) of thiosulphate used in blank

$\mathrm{N}=$ Normality of thiosuphate $\left(\mathrm{Na}_{2} \mathrm{~S}_{2} \mathrm{O}_{3}\right)$

\section{Determination of acid value}

The acid value of oil sample was determined by direct titration in alcoholic solution with aqueous $\mathrm{NaOH}$, the result being expressed in (mg/KOH/g) (ASTM, 1994).

Reagents used: 

a) Ethanol $95 \% \mathrm{v} / \mathrm{v}$
b) $0.1 \%$ Phenolphthalein
c) $0.1 \mathrm{~N} \mathrm{NaOH}$

Procedure:

i. $\quad 0.35 \mathrm{~g}$ of the sample was weighed accurately on the watch glass.

ii. It was washed into a $450 \mathrm{ml}$ beaker flask with $100 \mathrm{ml}$ ethanol

iii. The solution was then heated in a steam bath until boiling temperature after which two drops of phenolphthalein indicator was added.

iv. It was titrated against $0.1 \mathrm{~N} \mathrm{NaOH}$ until it became slightly pink.

v. The solution was then re-boiled in the steam bath to ensure that the colour remained permanently pink.

vi. The reading of the burette during titration was recorded.

Calculation is as follows:

Acid Value $=\frac{[5.61 \times \mathrm{V}]}{\mathrm{W}}$

where,

$\mathrm{V}=$ Volume $(\mathrm{ml})$ of $\mathrm{NaOH}$ used

$\mathrm{W}=$ Weight (in g) of sample used

\section{Determination of percentage free fatty acid}

Percentage free fatty acid (\% FFA) (as oleic) was determined by multiplying the acid value with the factor 0.503 . Therefore,

$\%$ FFA $=0.503 \times$ acid value

\section{Production of alkyd resin}

The following reagents were used in this study for alkyd resin synthesis:

i. Phthalic anhydride

ii. Glycerol

iii. Hydrochloric acid

iv. Marble chips $\left(\mathrm{CaCO}_{3}\right)$

v. Oxygen scavenger (Antioxidant)

The procedure for alkyd resin synthesis involved two stages which include; alcoholysis and esterification. 


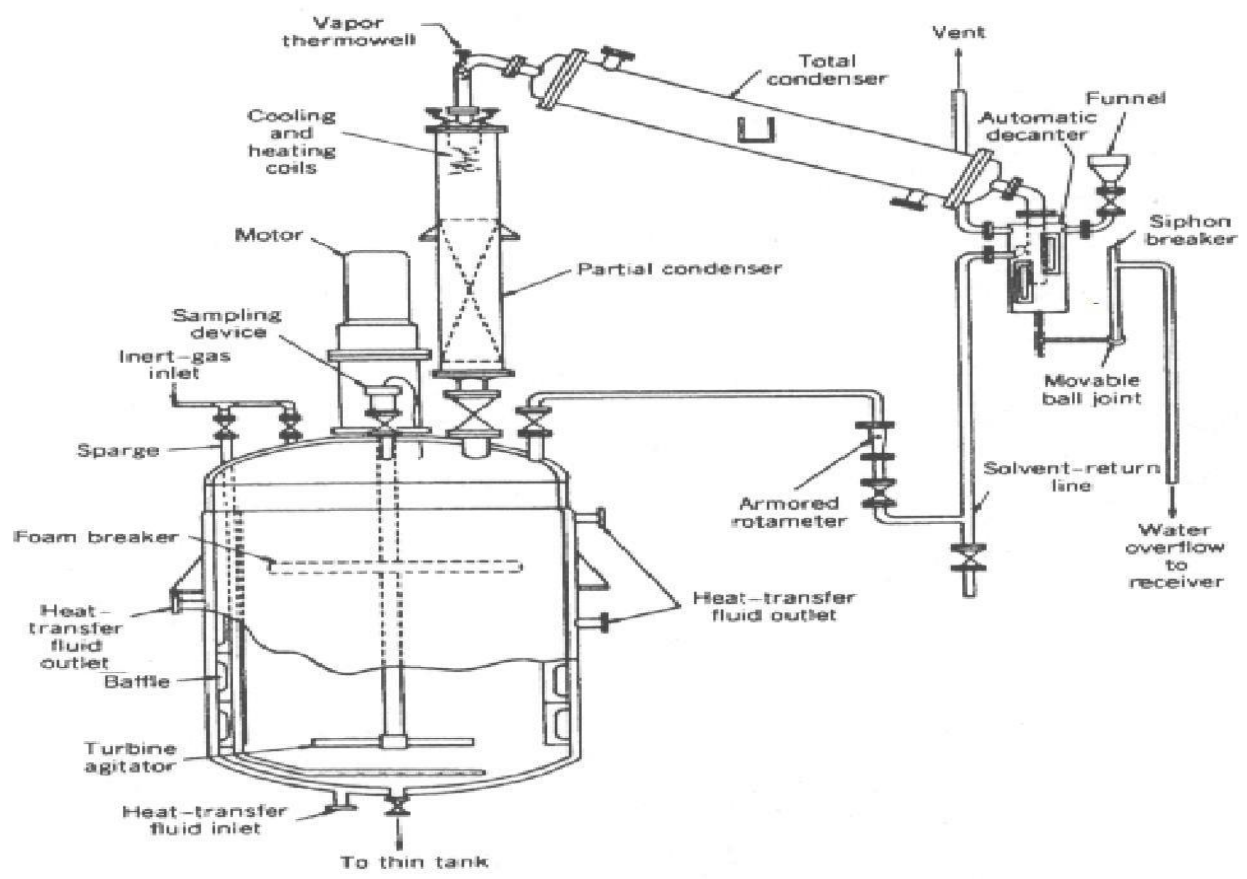

Figure 3: Scheme of alkyd resin reactor (Santos et al., 2005)

\section{Alcoholysis stage}

After setting up the above apparatus (Figure 3), $50 \mathrm{~g}$ of the oil sample and $2 \mathrm{~g}$ of $\mathrm{CaCO}_{3}$ (catalyst) were charged into the reactor. The mixture was heated up to about $120^{\circ} \mathrm{C}$. At $120^{\circ} \mathrm{C}, 20 \mathrm{~g}$ of glycerol was added and heated up to $180-190^{\circ} \mathrm{C}$, maintained for 30 minutes with vigorous agitation to cause trans-esterification of triglyceride into a mixture of mono- and diglyceride oils.

\section{Esterification stage}

The temperature was lowered to $150^{\circ} \mathrm{C}$ after 30 minutes, followed by the addition of $25 \mathrm{~g}$ phthalic anhydride after which the temperature was increased to $245^{\circ} \mathrm{C}$ continuous stirring to build the molecular weight of the resin. Excess phthalic anhydride (5g) was added to remove the water produced as by-product and to increase reaction rate. Water was thus removed with the unreacted acid by heating the bulk to temperature above $250^{\circ} \mathrm{C}$ with continuous stirring.

The process of reaction was monitored by periodically checking of acid number and viscosity. The resulting solution was stopped when it was fairly viscous and acid value found below10. Then, it was cooled to some extent and poured into storage container, while still hot for further study. Acid value of the in-process sample taken at intervals was determined by titrating with a $0.1 \mathrm{M} \mathrm{KOH}$ solution to the phenolphthalein end point after dissolution in a mixture of toluene and ethanol (1:1) (Bobalek and Chiang, 1964).

The acid value is related to the extent of the reaction $R_{e}$ and the average degree of polymerization $D_{p}$ as thus:

$$
\begin{aligned}
& R_{e}=\frac{A_{o}-A_{t}}{A_{o}} \\
& D_{p}=\left(1-R_{e}\right)^{-1}
\end{aligned}
$$

The rate equation for the reaction is expressed as:

$$
\left(1-R_{e}\right)^{-1}=A_{o}(k t+1)
$$


where $A_{o}$ is the initial acid value, $A_{t}$ is the acid value after time, $t$, of the reaction, $k$ is the rate constant and $t$ is the time of reaction (Oladipo et al., 2013).

\section{Physico-chemical Characterization of the alkyd resin}

\section{Determination of Specific gravity}

The specific gravity (SG) of the alkyd sample was determined by the method described below:

A Picometer was rinsed with distilled water, followed by acetone and allowed to dry. The empty Picometer was weighed and recorded as $\mathrm{W}_{1}$. A known volume of water with the picometer was also weighed and recorded as $\mathrm{W}_{2}$. Another equal volume of the alkyd sample with the picometer was weighed and recorded as $\mathrm{W}_{3}$. The $\mathrm{SG}$ was calculated using the equation below:

$\mathrm{SG}=\frac{\left\lfloor\mathrm{W}_{3}-\mathrm{W}_{1}\right\rfloor}{\left[\mathrm{W}_{2}-\mathrm{W}_{1}\right]}$

\section{Determination of refractive index}

Refractive index of each alkyd was determined at $30^{\circ} \mathrm{C}$ using Abbe's refractometer. The machine was turned. The cell was rinsed with water, followed by acetone and allowed to dry by draining it. The sample was added into the cell and the reading taken respectively.

\section{Determination of viscosity}

Viscosity of the alkyd was determined at $30^{\circ} \mathrm{C}$ using a Viscometer. The Viscometer was rinsed with organic solvent (acetone) and allowed to dry. A small quantity of the oil sample was added from one end of the viscometer with Micro pipette to fill the mark. At the release of each sample, a stop watch was put on and the time taken for the oil to flow from the point of origin to the calibrated mark was noted. The reading of the calibrated mark reached at an interval of time was taken and multiplied by a constant factor $\left(0.2483 \mathrm{~m}^{2} / \mathrm{S}\right)$ to obtain the sample's viscosity.

\section{Determination of acid value}

It was calculated using the same formula and procedure as that used in the characterization of seed oil in accordance with the method of Saad et al. (2007).

Calculation is as follows:

Acid Value $=\frac{[5.61 \times \mathrm{v}]}{\mathrm{W}}$

where,

$\mathrm{V}=$ Volume $(\mathrm{ml})$ of $\mathrm{NaOH}$ used

$\mathrm{W}=\mathrm{Weight}$ in grams of sample used

\section{Determination of iodine value}

Iodine value is used to determine the amount of unsaturation present in alkyd samples. Iodine is only slowly absorbed by the sample but is rapidly taken up by Wijs solution, which consists of a solution of iodine monochloride (ICl) in glacial acetic acid and Carbon tetrachloride. The unsaturated bonds present takes up the iodine to saturate the double bonds and the remaining unabsorbed iodine is then titrated by means of sodium thiosulphate.

Reagents used:

i. Carbon tetrachloride $\left(\mathrm{CCl}_{4}\right)$, inert to Wijs solution

ii. $\quad 10 \%$ solution of Potassium Iodide (KI)

iii. $\quad 0.1 \mathrm{~N}$ Sodium thiosulphate $\left(\mathrm{Na}_{2} \mathrm{~S}_{2} \mathrm{O}_{3}\right)$

iv. Iodine trichloride $\left(\mathrm{ICl}_{3}\right)$ 

v. Glacial acetic acid
vi. Potassium dichromate
vii. Hydrochloric acid $(\mathrm{HCl})$ free from chlorine
viii. Freshly prepared soluble Starch solution (1g of starch in $100 \mathrm{ml}$ of water)

Procedure:

a) $\quad 0.49 \mathrm{~g}$ of sample was dissolved in $15 \mathrm{ml} \mathrm{CCl}_{4}$ in a clean dry glass bottle with a fitting glass stopper.

b) $20 \mathrm{ml}$ of Wijs solution was added and sealed effectively by moisturing the stopper with a minimum quantity of $10 \% \mathrm{KI}$.

c) The bottle was allowed to stand for 30 minutes at a temperature of $15^{\circ} \mathrm{C}-20^{\circ} \mathrm{C}$ in a dark place.

d) After 30 minutes, $15 \mathrm{ml}$ of $10 \% \mathrm{KI}$ solution and $10 \mathrm{ml}$ of distilled water was added.

e) The solution was then titrated with $0.1 \mathrm{~N} \mathrm{Na}_{2} \mathrm{~S}_{2} \mathrm{O}_{3}$ solution using Starch as an indicator.

f) A blank experiment was also carried out using the same procedure without use of the sample.

The calculation is giving as:

Iodine Value $=\frac{12.69\left[\mathrm{~V}_{1}-\mathrm{V}_{2}\right]}{\mathrm{W}} \times 0.1$

where,

$\mathrm{V}_{1}=$ Volume (ml) of thiosulphate solution used in the blank

$\mathrm{V}_{2}=$ Volume (ml) of thiosulphate solution used in the test

$\mathrm{W}=$ Weight $(\mathrm{g})$ of alkyd sample

\section{Determination of saponification value}

It was calculated using the same formula and procedure as that used in the characterization of seed oil as described by Saad et al. (2007).

The calculation is given as

Saponification Value $=\frac{56.1 \mathrm{~N}\left[\mathrm{~V}_{1}-\mathrm{V}_{2}\right]}{\mathrm{W}}$

where,

$\mathrm{N}=$ Normality of $\mathrm{HCl}$ acid used

$\mathrm{V}_{1}=$ Volume of Hydrochloric acid used in the blank.

$\mathrm{V}_{2}=$ Volume of Hydrochloric acid used in the test.

$\mathrm{W}=$ Weight of alkyd sample used.

\section{Matlab Modelling of the Equation for the Extent of Reaction}

Since there was no theoretical model available for the extent of reaction in the synthesis of alkyd resins from the oils of the indigenous seeds, MATLAB was used to generate model equations for this time dependent parameter. This model equation would be very useful as it will help predict the time at which the highest conversion will be obtained and also the efficiency of the conversion. The compliance of the generated model with the experimental results ascertains the efficacy of the equation. 


\section{Structural Analysis by Fourier Transfer Infrared Spectroscopy (FTIR)}

The infrared spectrum provides information on the type of alkyd resin under examination and the main constituents from which the resin is made including any modifying agents can be recognized. FTIR spectra of the alkyd sample were obtained using FTIR-8400S Fourier Transfer Infrared Spectrophotometer.

\section{Performance characteristics of the alkyd resin}

The performance characteristics of the frywood seed oil alkyd film and the commercially produce alkyd film were determined in terms of drying process and chemical resistance using different solvent media such as acid, alkali and water using standard methods as reported in the previous studies (Atta et al., 2013; Ikyenge et al., 2015).

\section{Determination of drying process test}

The solution of each of the alkyds in xylene together with the drying agents (cobalt naphthanate and lead naphthanate) were applied on a clear glass panel and dried at room temperature to study the film performance property. The drying process was monitored in terms of the time of set-to- touch, surface-dry and dry-through. In all of the comparative examples, the tests were carried out under similar conditions and the results are comparable. Below is the formula to ascertain the amount of dryer required:

The amount of dryer required $=$ weight of resin taken $\times \%$ of metal required

$$
\text { Percentage metal in dryer }
$$

\section{Determination of chemical resistance test}

The chemical resistance was determined at room temperature using the method reported by Momodu et al. (2011). The ends of the glass panels of each alkyd films were coated with wax in order to prevent migration under the film from the open ends. The panels were then dipped (immersed) into water, $3 \%(\mathrm{v} / \mathrm{v}) \mathrm{H}_{2} \mathrm{SO}_{4}$ and $1 \%(\mathrm{w} / \mathrm{v}) \mathrm{NaOH}$ and were examined for the change in appearance at intervals of time and the time noted when the first noticeable effect or attack appeared, and also when the film was completely destroyed. In all of the comparative examples, the tests were carried out under similar conditions and the results are comparable.

\section{RESULTS AND DISCUSSION}

\section{Physico-chemical properties of the seed oil}

The physicochemical properties of the oil sample extracted from Albizia lebbeck (frywood) seeds are as shown in the Table 1.

Table 1: $\quad$ Physico-chemical properties of frywood seed oil (FWO)

\begin{tabular}{|l|c|}
\hline \multicolumn{1}{|c|}{ Parameter/ Unit } & FWO \\
\hline Colour & Yellow \\
\hline Oil Yield $(\% \mathrm{w} / \mathrm{w})$ & 17.32 \\
\hline Density $\left(\mathrm{g} / \mathrm{cm}^{3}\right)$ & 0.89 \\
\hline Specific Gravity $\left(30^{\circ} \mathrm{C}\right)$ & 0.84 \\
\hline Refractive Index $\left(30^{\circ} \mathrm{C}\right)$ & 1.48 \\
\hline Viscosity $\left(30^{\circ} \mathrm{C}\right)\left(\mathrm{m}^{2} / \mathrm{S}\right)$ & 27.06 \\
\hline $\begin{array}{l}\text { Saponification Value } \\
(\mathrm{mgKOH} / \mathrm{g})\end{array}$ & 207.22 \\
\hline Iodine Value $(\mathrm{gI} / \mathrm{l} / 100 \mathrm{~g})$ & 122.18 \\
\hline Acid Value $(\mathrm{mgKOH} / \mathrm{g})$ & 8.98 \\
\hline
\end{tabular}




\begin{tabular}{|l|c|}
\hline Free Fatty Acids (\%) & 4.52 \\
\hline Peroxide Value (mEq/kg) & 10.00 \\
\hline
\end{tabular}

From Table 1, the colour of FWO was yellow and it remained liquid at room temperature. Colours in seed oils are most likely due to the presence of natural pigments like carotenoids, tocopherols and their derivatives (Okolie et al., 2012). The refractive index of the oil was 1.48 which falls within the range of refractive indices of drying oils (1.46-1.54) and this suggests that the refractive index can be used as a test for purity and as an aid to identification (Oladipo, 2013).

The oil content for frywood seed was found to be $17.32 \% \mathrm{w} / \mathrm{w}$ (Table 1). The value in some cases was comparable to those reported for the seeds earlier studied (Nzikou et al., 2010; Abayeh et al., 2011). However, the low percentage oil yield may not be unconnected to the fact that manual removal of the seed coat was impossible; as such the cotyledons were inseparable from the coat. The seed coat and cotyledons were thus ground into a powdery form for the purpose of extraction. The seed coat with little or no oil included in the weight of the ground seed may have contributed to the reduction in the calculated oil yield.

Specific gravity and density are important physical characteristics indicative of the handling and storage of oils and fuels as well. The specific gravity of oil is the ratio of the mass of a given volume of oil to the mass of an equal volume of water; it is related to the fatty acid content of the oil and the average molecular weight. The specific gravity and density values obtained for frywood seed oil in this study (Table 1) compare favourably with those of canola oil, rubber seed oil and soybean oil (Ikhuoria et al., 2004; Barnwal and Sharma, 2005) and other seed oils reported by Ogbobe (1992), Mariod et al. (2004) and Zimba et al. (2005). The value suggests that FWO may find outlets in the manufacture of lubricants and other purposes like biodiesel production.

The acid value is a measure of the free fatty acid content in oil. It is affected by the duration and conditions of storage of the oil. Acid value is an indicator of the edibility of oil and its suitability for industrial use (Abu-Sayeed et al, 2004; Abayeh et al, 2011). The acid value of FWO was low $(8.98 \mathrm{mgKOH} / \mathrm{g}$ ) compared to other industrially useful oils (Okolie et al., 2012). Hence, the low value obtained for these seed oils is an indication of good non-degraded state of the lipids and is within limits for industrially useful oils. In general, the low acid value for the oil is suggestive of its usefulness in the manufacture of paints and varnish (Okolie et al., 2012). The free fatty acid value of oil on the other hand is a measure of the enzymatic hydrolysis the oil has undergone in the parent source before extraction. It was observed that the free fatty acid concentration of the oil (4.52\%) was low which was consistent with the low acid value observed (Table 1).

The peroxide value indicates the level of deterioration of oil as a result of oxidation owing to the availability of oxygen during storage. Peroxide value can be a useful early indicator of oxidative deterioration and a decrease in the effectiveness of the oils own antioxidants. During oxidative deterioration the peroxide value first rises and then falls after reaching a maximum value. During storage, peroxides are generated by oxygen access in which increase in viscosity and gummy deposits can be the consequence. The peroxide value of FWO $(10.00 \mathrm{mEq} / \mathrm{kg}$ ) (Table 1) compares favourably with commercial vegetable oils as reported by Majumder (1990) in linseed oil, Ikhuoria \& Okieimen (2005) in rubber seed oil, Onukwli and Igbokwe (2008) in castor seed oil and Oladipo et al. (2013) in wild olive seed oil, suggesting that the oil is stable to oxidative rancidity.

Saponification value gives an indication of the size of the hydrocarbon chain; it is a measure of the average molecular weight of the triacylglycerol in oil. This parameter is significant in soap manufacturing industries and also in biodiesel production. The lower the saponinfication value, the higher the molecular weight of the hydrocarbon and vice versa. The saponification value of the plant's seed oil suggests that the oil can be used for soap production. The saponification value $(207.15 \mathrm{mgKOH} / \mathrm{g}$ ) (Table 1) is higher in comparison with the corresponding values for rubber seed, castor seed and linseed oils which had 181.14, 182 and 185-194mgKOH/g respectively (Onukwli and Igbokwe, 2008; Majumder, 1990; Ikhuoria and Okieimen, 2005). 
Iodine value measures the degree of unsaturation on the hydrocarbon ends of oils; it is useful in predicting the drying property of oils (Özcan and Atalay, 2006; Abayeh et al., 2011). Generally, oils are classified into three categories based on their iodine values; oils with iodine values of 80-120 are non-drying oils, 120-150, semi drying oils and drying oils have iodine values greater than 150 (Abayeh et al., 2011). Thus going by this classification, FWO with iodine value of $122.18 \mathrm{gI} / 200 \mathrm{~g}$ (Table 1 ) can be classified as semi drying oil. As such in addition to their possible use for biodiesel production, they can also be useful in surface coating applications like paints, alkyd resins and printing inks. The iodine value of FWO showed comparable iodine value with those of safflower, sunflower and soya bean oils (with iodine values ranging between 112 and 148) (Abayeh et al., 2011).

\section{Physico-chemical characterization of the alkyd resins}

The course of the reaction was controlled by monitoring the increase in viscosity of the resin (which reflects the increase in molecular weight) and by the determination of acid value. Table 2 shows the physico-chemical properties of the alkyd sample prepared from the reaction between the seed oil, glycerol and phthalic anhydride. Their physico-chemical properties were compared with those of the commercially prepared alkyd.

Table 2: Physico-chemical properties of the frywood seed oil alkyd resins (FWOAR) compared with the commercially prepared alkyd resin (CPAR)

\begin{tabular}{|l|c|c|}
\hline \multicolumn{1}{|c|}{ Parameter/ Unit } & FWOAR & CPAR \\
\hline Colour & Dark Brown & Colourless \\
\hline Specific Gravity $\left(30^{\circ} \mathrm{C}\right)$ & 47.70 & 47.40 \\
\hline Viscosity $\left(30^{\circ} \mathrm{C}\right)\left(\mathrm{m}^{2} / \mathrm{S}\right)$ & 36.50 & 32.34 \\
\hline $\begin{array}{l}\text { Saponification } \mathrm{Value} \\
(\mathrm{mgKOH} / \mathrm{g})\end{array}$ & 361.85 & 263.97 \\
\hline $\begin{array}{l}\text { Iodine Value }(\mathrm{gI} / 100 \mathrm{~g}) \\
\end{array}$ & 32.33 & 78.22 \\
\hline Acid Value $\left(\mathrm{mgKOH}_{2} \mathrm{~g}\right)$ & 7.01 & 6.31 \\
\hline
\end{tabular}

The colour of the alkyd is dark-brown as compared to that of the commercially prepared alkyd (colourless) (Table 2). The darkening in colour of the alkyd could be attributed to high temperatures of reaction, oxidation and the catalyst (MacDonald et al., 1994).

The iodine value of the alkyd resin was observed to have decreased considerably to $32.33 \mathrm{gI}_{2} / 100 \mathrm{~g}$ as compared to $139.62 \mathrm{gI}_{2} / 100 \mathrm{~g}$ of the crude seed oil. This could be as a result of dimerization and polymerization reactions at the reactive double bonds of unsaturation of the oil during alkyd synthesis. The range of the iodine values $\left(30-60 \mathrm{gI}_{2} / 100 \mathrm{~g}\right)$ shows that it may be of the same class of semidrying oil but that of the commercially prepared alkyd $\left(78.22 \mathrm{gI}_{2} / 100 \mathrm{~g}\right)$ was suggested to be in the class of drying oil. The result of the iodine value is supported by the reports of Ikhuoria et al. (2004), Momodu et al. (2011) and Igbo et al. (2014) on the iodine value of rubber seed oil alkyd resin, walnut seed oil alkyd resin and beniseed oil alkyd resin respectively.

The saponification value of the alkyd resin $(361.85 \mathrm{mgKOH} / \mathrm{g})$ was observed to have relatively increased compared to the seed oil $(167.32 \mathrm{mgKOH} / \mathrm{g})$ and this could be due to polymerization reaction (Momodu et al., 2011). The test alkyd was also observed to have relatively high saponification value compared to that of the commercially prepared alkyd $(263.97 \mathrm{mgKOH} / \mathrm{g})$. This suggests that the 
seed oil may be of great important in industrial purposes such as soap and paint productions and the result is in tandem with the reports of Ikhuoria et al. (2004), Momodu et al. (2011) and Igbo et al. (2014).

The specific gravity and the viscosity of the test alkyd resin at $30^{\circ} \mathrm{C}$ were observed to be relatively high compared to their corresponding values obtained in the seed oil. This could be as a result of polymerization reactions at the reactive double bonds of unsaturation of the oil and increased molecular weights during alkyd synthesis. However, at $30^{\circ} \mathrm{C}$, the specific gravity (47.70) and the viscosity $\left(36.50 \mathrm{~m}^{2} / \mathrm{S}\right)$ of the test alkyd resin (Table 2) were non-significantly higher than the specific gravity (47.40) and the viscosity $\left(32.34 \mathrm{~m}^{2} / \mathrm{S}\right)$ of the commercially prepared alkyd resin. These values were comparable with that obtained in the report of Singh (2009) suggesting that the test alkyd resin will be preferable to the commercially available types for industrial applications if well harnessed. Alkyd resin produced from the FWO showed acid value $(7.01 \mathrm{mgKOH} / \mathrm{g})$ (Table 2) that is non-significantly higher than the acid value of the commercially prepared alkyd resin $(6.31 \mathrm{mgKOH} / \mathrm{g})$ and is in line with those obtained in the literature survey $(5.61$ $8.6 \mathrm{mgKOH} / \mathrm{g}$ ) as reported by Oladipo et al. (2013) and Igbo et al. (2014) for wild olive seed oil and beniseed oil respectively. However, the test alkyd resin showed lower acid values compared to those of deodourizer distillate, soyabean oil and walnut seed oil (9.6-14.24mgKOH/g) as reported by Singh (2009), Aghaie et al. (2010) and Momodu et al. (2011) respectively. Acid value in alkyd is an important parameter in determining the chemical resistance of alkyd resin to various solvent media such as water, brine ( $\mathrm{NaCl}$ ), acid $\left(\mathrm{H}_{2} \mathrm{SO}_{4}\right)$ and alkali $(\mathrm{KOH})$; since the lower the acid value of an alkyd resin, the higher its chemical resistance to various solvent media and vice versa (Ikhuoria et al., 2004). The low acid value exhibited by the alkyd resin suggests that it is promising in formulating coatings like nitrocellulose lacquers for metal cans used in packaging foods, beverages and drugs.

\section{Variations in acid value (AV), viscosity, extent of reaction $\left(R_{e}\right)$ and degree of polymerization $\left(D_{p}\right)$ of in-process alkyd sample with time}

Figures 3, 4, 5 and 6 illustrate the variations in AV, viscosity, $R_{e}$ and $D_{p}$ of in-process sample of frywood oil alkyd resin with time during alkyd resin production. The kinetics of polyesterification reaction was monitored by determining the acid value for the aliquot of the reaction mixture at various time intervals beside the volume of water evolved. In addition, the increasing viscosity of the alkyd samples was reduced as the reaction progressed (Figure 4). This was corroborated by the changes in acid value with reaction time as shown in Figure 3, which revealed that there was an initial sharp decrease in acid value followed by a more gradual decrease. Similar observations have been reported (Ikhuoria et al., 2007; Onukwli and Igbokwe, 2008; Oladipo et al., 2013; Igbo et al., 2014).

The decrease in acid value may be attributed to desperate reactivities of primary and secondary hydroxyl groups of glycerol with carboxyl groups of phthalic anhydride. It is also attributable to incorporation of almost all reactants in the polymer chain at the initial stage of reaction, characteristics of step-growth polymerization. It has been reported that the primary hydroxyl groups of the monoglyceride react more rapidly than the secondary hydroxyl groups with carboxyl groups of phthalic anhydride. It is has been reported that at a temperature of about $160{ }^{\circ} \mathrm{C}$, primary hydroxyl groups of glycerol react rapidly with carboxyl groups of phthalic anhydride, while secondary hydroxyl groups react at temperature above $230{ }^{\circ} \mathrm{C}$ (Goldsmith, 1948). Thus, the initial marked decrease in acid value observed for the alkyd sample may be due to increase in the rate of esterification accompanying the rapid increase in temperature to $230^{\circ} \mathrm{C}$. 


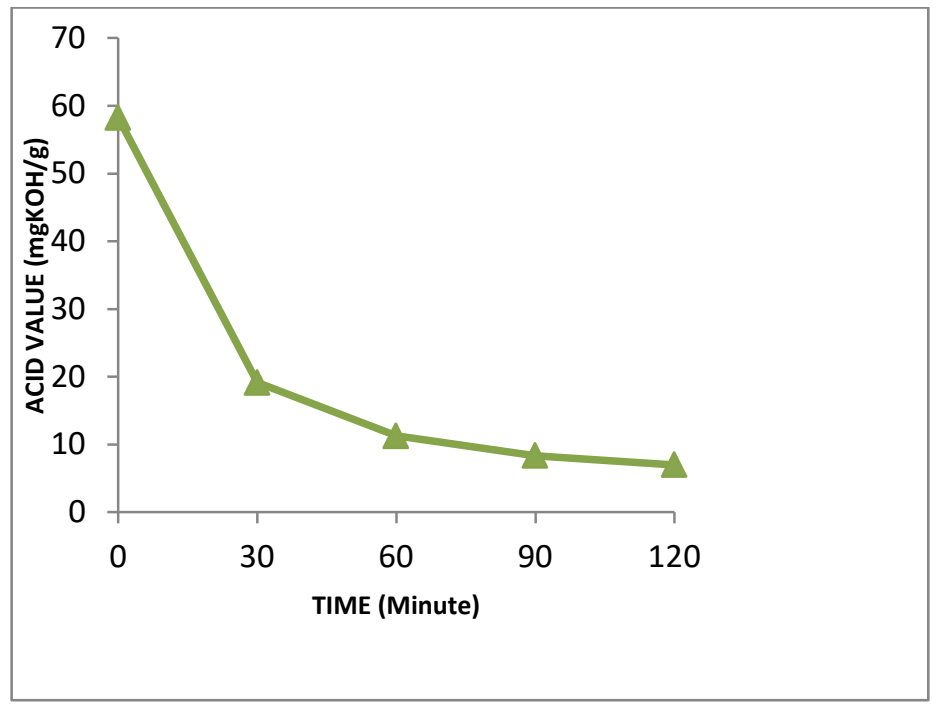

Figure 3: Plot of change in acid value versus reaction time for FWOAR.

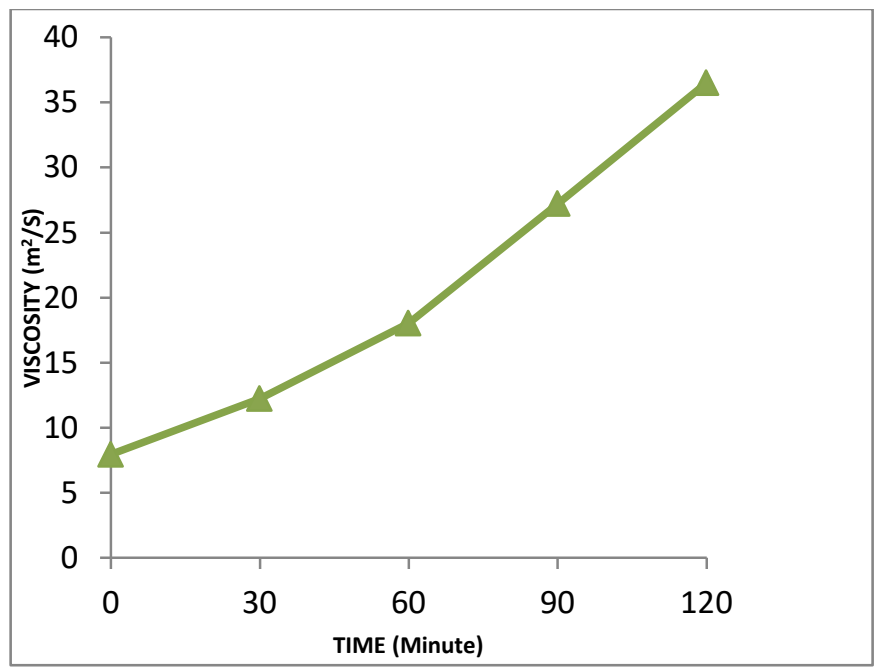

Figure 4: Plot of change in viscosity versus reaction time for FWOAR.

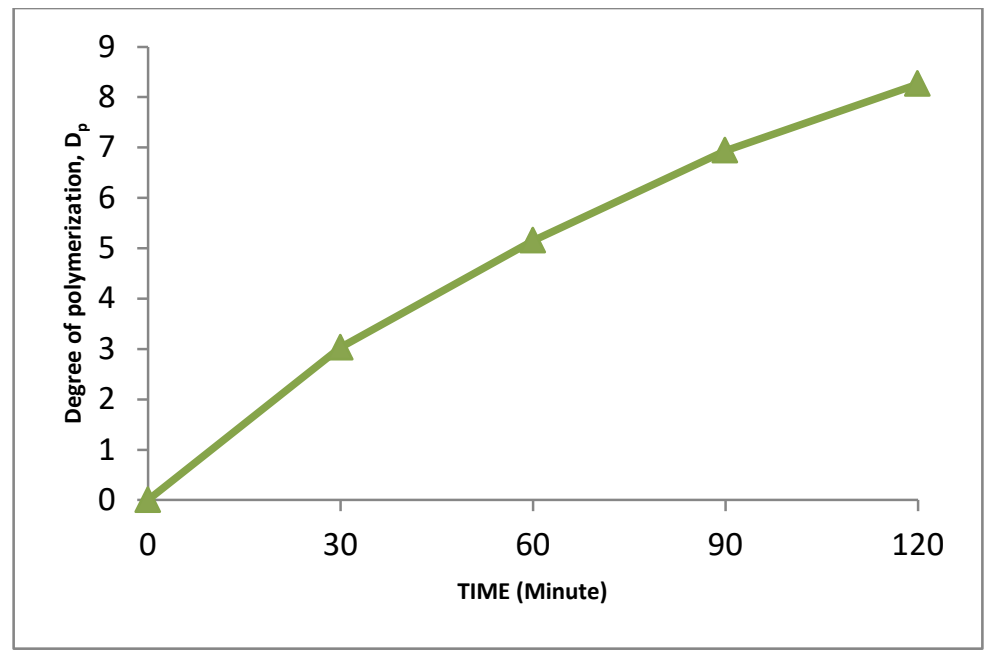

Figure 5: Plot of degree of polymerization versus reaction time for FWOAR. 
The variation in the average degree of polymerization $\left(\mathrm{D}_{\mathrm{p}}\right)$ with reaction time is shown in Figure 5. The first region of this plot shows the period when the primary hydroxyls of glycerol reacted with carboxyl groups of phthalic anhydride leading to formation of linear chain. Immediately the primary hydroxyl groups are esterified, there is an abrupt drop in acid value (Fig. 3) and the reaction slackens until a temperature is reached when the secondary hydroxyl groups begin to react (Aigbodion and Okieimen, 1996). Thus, the increasing $\mathrm{D}_{\mathrm{p}}$ of the alkyd chains results in increasing viscosity of the reaction medium.

Contrary to acid value, it was observed that there was an initial sharp increase in the extent of reaction followed by a more gradual increase (Figure 6) and is in tandem with the reports of Oladipo et al., 2013 and Igbo et al., 2014. However, in polyesterification reactions, the reactivity of the functional group does not depend on the size of molecule to which it is attached (Aigbodion and Okieimen, 1996).

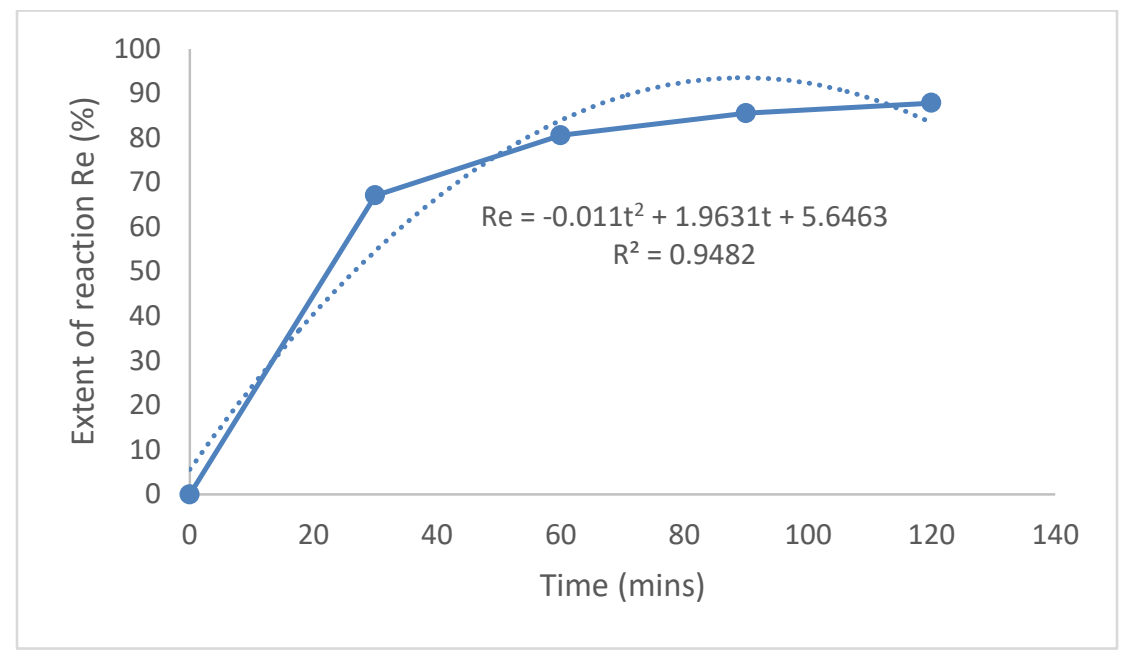

Figure 6: Plots of extent of reaction versus reaction time for FWOAR

\section{Generated Model Equations for the Extent of Reaction for the Alkyd Resin}

The generated model equations for the extent of reaction for the alkyd resin are given in Table 3 below.

Table 3: Equations for the extent of reaction for the alkyd resin

\begin{tabular}{|l|c|c|}
\hline \multirow{2}{*}{ ALKYD RESIN } & \multicolumn{2}{|c|}{ EQUATIONS } \\
\cline { 2 - 3 } & THEORETICAL & EXPERIMENTAL \\
\hline FWOAR & $\frac{98.32 t-0.1818}{t+13.75}$ & $-0.011 \mathrm{t}^{2}+1.9631 \mathrm{t}+5.6463$ \\
& & \\
\hline
\end{tabular}

The generalized form of the equation is as shown below.

For the theoretical model, we have

$R_{e}=\frac{a t-b}{t+c}$

1

For the experimental model, we have

$R_{e}=-a t^{2}+b t+c$ 2 
where $R_{e}$ is the extent of reaction, $t$ is reaction time and $a, b$ and $c$ are constants specific to the specimens.

Figure 7 illustrates the modelling of the equations for the extent of reaction of the alkyd resin.

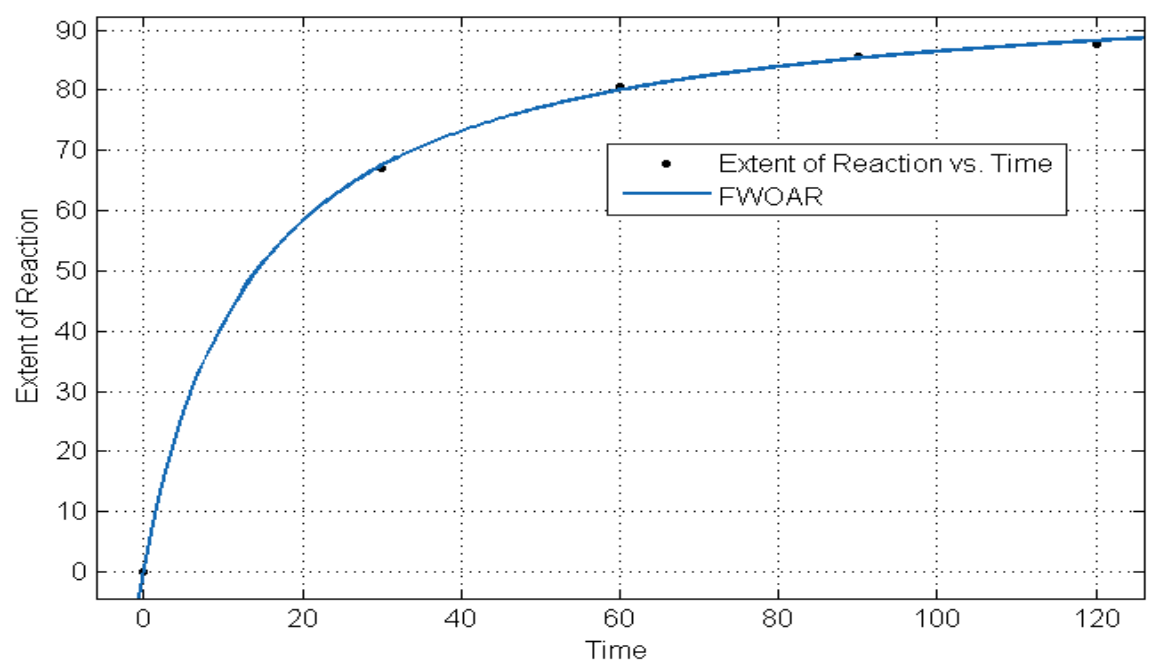

Figure 7: Generated model for the extent of reaction versus reaction time for FWOAR

\section{Structural Analysis of the Alkyd Resins}

The Fourier Transform Infra-red Spectroscopy (FTIR) technique is an important tool to identify the characteristic functional groups, which are instrumental in determination of functional groups and organic compounds inherent in any tested sample. This study is thus aimed at showcasing the functional groups and compounds present in the produced alkyd resin. The FTIR spectra of alkyd resin from the oil of Albizia lebbeck, and those of the commercially produced alkyd resin were shown in Figures 8 and 9. Tables 4 and 5 show the functional groups and compounds relatively present in the alkyd resin produced from seed oil of Albizia lebbeck (frywood plant) and those of the commercially produced alkyd resin respectively. The wavelength, functional groups and compounds present in Albizia lebbeck (frywood plant) seed oil alkyd resin are shown in Table 4 below.

The broad bands around $3438.23 \mathrm{~cm}^{-1}$ were assigned to hydroxyl $\mathrm{OH}$ group of unsaturated fatty acid. The weak band around 2933.83 $\mathrm{cm}^{-1}$ and $2647.39 \mathrm{~cm}^{-1}$ were due to SCN and CO stretch of thiocyanate and free carbonyl compounds of unsaturated fatty acid. The peak value at $1717.67 \mathrm{~cm}^{-1}$ were attributed to $\mathrm{CO}$ stretch of cyclic ester compounds of monoglyceride, while the peak height at $1127.43 \mathrm{~cm}^{-1}$ corresponds to $\mathrm{CH}$ stretch of vinylidene compound of unsaturated alkene compounds.

Table 4: Interpretation of FTIR Spectra of frywood alkyd resin

\begin{tabular}{|c|c|c|c|}
\hline S/N & WAVELENGTH $\left(\mathbf{c m}^{-\mathbf{1}}\right)$ & $\begin{array}{c}\text { FUNCTIONAL } \\
\text { GROUP }\end{array}$ & COMPOUNDS \\
\hline 1 & 406.99 & $\mathrm{C}-1$ & Aliphatic Iodo compound C-1 stretch \\
\hline 2 & 1063.78 & $\mathrm{Si}-\mathrm{O}-\mathrm{Si}$ & Silane SiO stretch \\
\hline 3 & 1127.43 & $\mathrm{H}_{2} \mathrm{C}=\mathrm{CH}_{2}$ & Vinylidene $\mathrm{CH}$ asymmetric stretch \\
\hline
\end{tabular}




\begin{tabular}{|c|c|c|c|}
\hline 4 & 1281.74 & $\mathrm{RNH}_{2}$ & $1^{\circ}$ amine NH stretch \\
\hline 5 & 1385.90 & $\mathrm{CH}_{3}$ & Methyl CH symmetric stretch \\
\hline 6 & 1654.01 & $\mathrm{R}_{2} \mathrm{NH}$ & $2^{\circ}$ amine NH stretch \\
\hline 7 & 1717.67 & $\mathrm{C}-\mathrm{O}-\mathrm{C}$ & Cyclic ester CO stretch \\
\hline 8 & 2076.44 & $\mathrm{RCOOH}$ & Carboxylic acid CO stretch \\
\hline 9 & 2647.39 & $\mathrm{R} 2 \mathrm{C}=\mathrm{O}$ & Carbonyl CO asymmetric stretch \\
\hline 10 & 2933.83 & $\mathrm{R}-\mathrm{S}-\mathrm{C} \equiv \mathrm{N}$ & Thiocyanate SCN asymmetric stretch \\
\hline 11 & 3438.23 & $\mathrm{RCHOH}$ & $1^{\circ}$ alcohol OH stretch \\
\hline
\end{tabular}

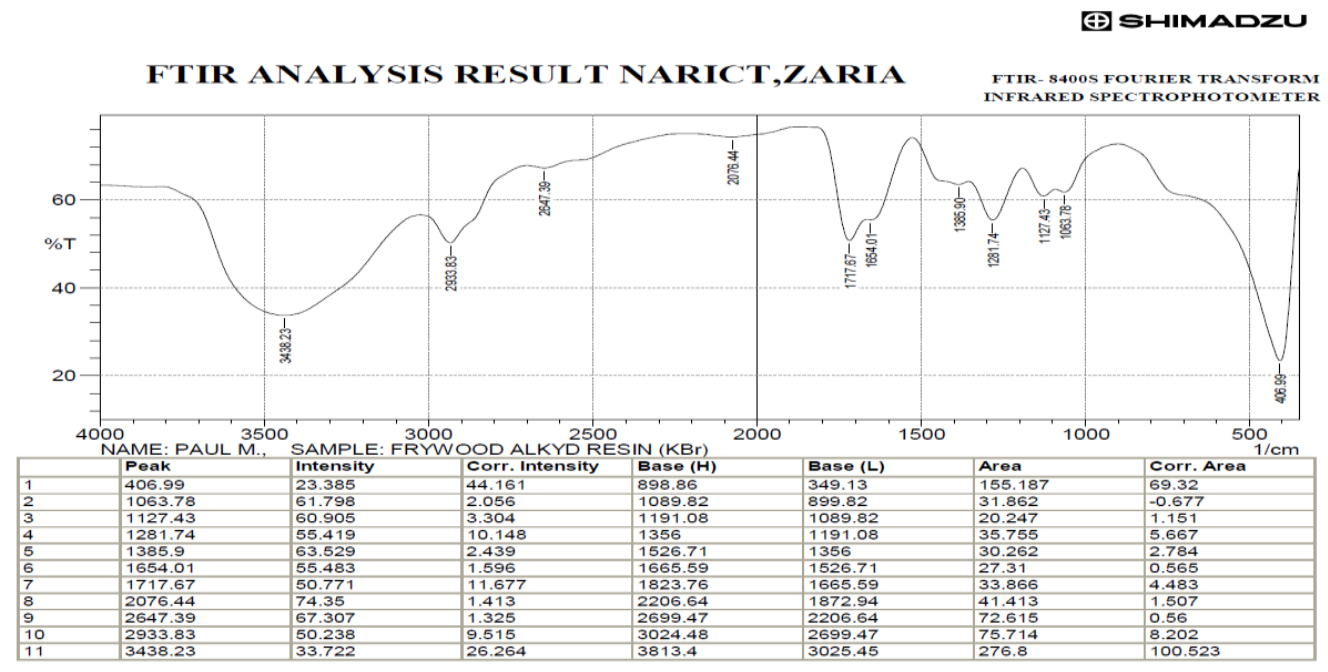

Comment;

NAME: PAUL M., SAMPLE: FRYWOOD ALKYD

User; $\quad$ Administrator

RESIN (KBr)

No. of Scans;

Date/Time; 10/5/2015 2:33:43 PM

Resolution;

Figure 8: FTIR Spectra of frywood alkyd resin

Table 5: Interpretation of FTIR spectra of commercial alkyd resin

\begin{tabular}{|c|c|c|c|}
\hline S/N & WAVELENGTH $\left(\mathbf{c m}^{-1}\right)$ & $\begin{array}{c}\text { FUNCTIONAL } \\
\text { GROUP }\end{array}$ & COMPOUNDS \\
\hline 1 & 401.21 & C-1 & Aliphatic Iodo compound C-1 stretch \\
\hline
\end{tabular}




\begin{tabular}{|c|c|c|c|}
\hline 2 & 449.43 & $\mathrm{C}-1$ & Aliphatic Iodo compound C-1 stretch \\
\hline 3 & 739.73 & $\mathrm{C}-\mathrm{Br}$ & Bromo compound $\mathrm{C}-\mathrm{Br}$ stretch \\
\hline 4 & 881.50 & $\mathrm{C}-\mathrm{Cl}$ & Chloro compound $\mathrm{C}-\mathrm{Cl}$ stretch \\
\hline 5 & 984.69 & $\mathrm{C}-\mathrm{F}$ & Fluoro compound CF stretch \\
\hline 6 & 1077.28 & $\mathrm{C}-\mathrm{O}-\mathrm{C}$ & Ether CO stretch \\
\hline 7 & 1131.29 & $\mathrm{H}-\mathrm{C}=\mathrm{CH}$ & Vinylidene $\mathrm{CH}$ asymmetric stretch \\
\hline 8 & 1278.85 & $\mathrm{RNH}_{2}$ & $1^{\circ}$ amine NH stretch \\
\hline 9 & 1452.45 & $\mathrm{CH}_{3}$ & Methyl CH symmetric stretch stretch \\
\hline 10 & 1612.54 & $\mathrm{R}_{2} \mathrm{NH}$ & $2^{\circ}$ amine $\mathrm{NH}$ stretch \\
\hline 11 & 1727.31 & $\mathrm{C}-\mathrm{O}-\mathrm{C}$ & Cyclic ester CO stretch \\
\hline 12 & 1961.67 & $\mathrm{R}-\mathrm{S}-\mathrm{C} \equiv \mathrm{N}$ & Thiocyanate SCN asymmetric stretch \\
\hline 13 & 2096.69 & $\mathrm{RCOOH}$ & Carboxylic acid CO stretch \\
\hline 14 & 2359.98 & $\mathrm{O}-\mathrm{C}-\mathrm{N}$ & Cyanide CN stretch \\
\hline 15 & 2653.17 & $\mathrm{R}_{2} \mathrm{C}=\mathrm{O}$ & Carbonyl CO asymmetric stretch \\
\hline 16 & 2880.78 & $\mathrm{CH}_{2}$ & Methylene $\mathrm{CH}$ symmetric stretch \\
\hline 17 & 2931.90 & $\mathrm{R}-\mathrm{S}-\mathrm{C} \equiv \mathrm{N}$ & Thiocyanate SCN asymmetric stretch \\
\hline 18 & 3500.92 & $\mathrm{RCHOH}$ & $1^{\circ}$ alcohol $\mathrm{OH}$ stretch \\
\hline 19 & 3851.97 & $\mathrm{R}_{3} \mathrm{CHOH}$ & $3^{\circ}$ alcohol OH stretch \\
\hline
\end{tabular}




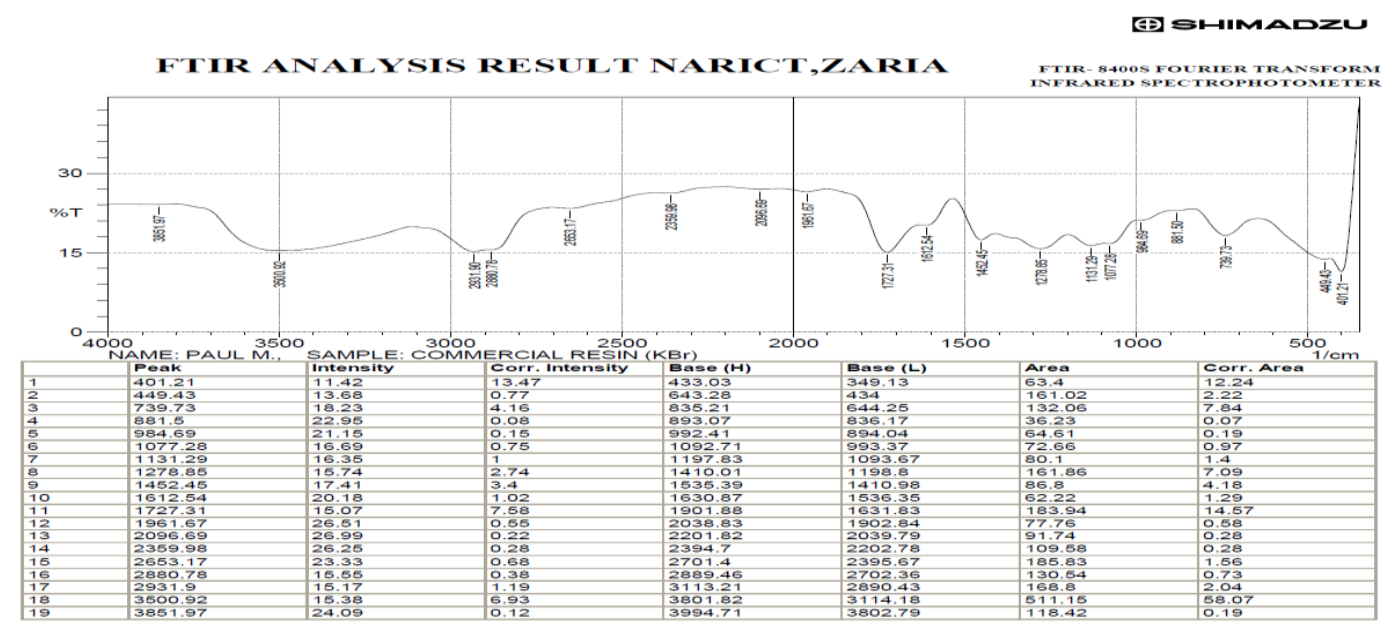

Comment;

NAME:

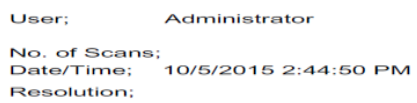

Figure 9: FTIR Spectra of commercially produced alkyd resin

The FTIR spectra and interpretation of commercial alkyd resin were shown in Figure 9 and Table 5 respectively. The free carbonyl and hydroxyl groups in the alkyd resin were observed at the band of $2653.17 \mathrm{~cm}^{-1}, 3500.92 \mathrm{~cm}^{-1}, 3851.97 \mathrm{~cm}^{-1}$. The peak value at $2931.90 \mathrm{~cm}^{-1}, 1961.67 \mathrm{~cm}^{-1}, 1131.29 \mathrm{~cm}^{-1}$ were assigned to $\mathrm{SCN}$ and $\mathrm{CH}$ stretch of thiocyanate and vinylidene compounds of unsaturated fatty acid of diglyceride and triglyceride (Gan and Teo, 1999). The peak height at $1727.31 \mathrm{~cm}^{-1}$ might be due to CO stretch of unsaturated cyclic ester of monoglyceride. The absorbance around $1077.28 \mathrm{~cm}^{-1}$ and $2096.69 \mathrm{~cm}-{ }^{1}$ suggest the CO stretch for ether and carboxylic compounds.

\section{Result of the Performance Characteristics of the Alkyd Resins}

\section{Drying characteristics of the alkyds}

The performance tests of each alkyd based on the drying process are shown in the Table 6 below.

\section{Table 6: Drying Properties of the Alkyd Resins}

\begin{tabular}{|l|c|c|}
\hline \multicolumn{1}{|c|}{ Drying Process } & \multicolumn{2}{c|}{ Drying Time (mins) } \\
\hline & FWOAR & CPAR \\
\hline Set-in-Touch & 120 & 60 \\
\hline Surface Drying & 405 & 230 \\
\hline Dry Through & 1080 & 585 \\
\hline
\end{tabular}

The drying schedules of the alkyd sample films were examined in terms of the times of set-to-touch, surface drying and dry-through. This is a very important consideration in coating formulation, as some coated surface may need to dry so that they can be put into service immediately after the coating has been supplied. Table 6 shows that film from the commercially prepared alkyd was set-to- 
touch around 60 minutes while that of the frywood seed oil alkyd was around 120minutes. It was also observed that surface drying process followed the same order as seen in set-to-touch time which was observed to be around 230 minutes and 405 minutes respectively for alkyd film from CPAR and FBAOR. The last drying process monitored (drying through) was first observed in CPAR film around 585 minutes and in FWOAR film around 1080 minutes. Drying is believed to occur through the process of autooxidation, which involves the adsorption of oxygen at the double bond of the unsaturated fatty acids (Ikhuoria et al., 2004) and that of the polybasic acid used in alkyd resin production (Ikyenge et al., 2015). The trend is therefore in agreement with the level of unsaturation as indicated by the iodine value of the corresponding alkyds in Table 2 and the higher the level of unsaturation, the faster is the drying time (Zeno et al., 1999). Another factor that can contribute to these differences in drying time of the alkyds could be the structure of the polybasic acid used in the alkyd resins preparation. For instance, phthalic anhydride has a benzene ring in its structure, which contains conjugated bonds that can enhance auto-oxidation process, maleic anhydride has a double bond in its aliphatic structure, which also enhances auto-oxidation and succinic acid has aliphatic carbon chain in its structure, without any double bond to facilitate auto-oxidation. However, from these results, it can be inferred that alkyd film from FWOAR will be very useful, if properly harnessed, for formulation of coatings and binders.

\section{Chemical resistance properties of the alkyds}

The chemical resistance tests of the seed oil alkyd based on the use of water, acidic and alkaline media were shown in the Table 7 below.

\section{Table 7: Chemical Resistance Properties of the Alkyd Resins}

\begin{tabular}{|c|c|c|}
\hline \multirow[t]{2}{*}{ Solvent Media } & \multicolumn{2}{|c|}{$\begin{array}{l}\text { Appearance within } 24 \\
\text { hours }\end{array}$} \\
\hline & FWOAR & CPAR \\
\hline Water $(6,12,18,24)$ & $\mathrm{n}, \mathrm{w}, \mathrm{s}, \mathrm{s}$ & $\mathrm{n}, \mathrm{n}, \mathrm{n}, \mathrm{s}$ \\
\hline $\mathrm{O.1M} \mathrm{H}_{2} \mathrm{SO}_{4}(6,12,18,24)$ & $\mathrm{n}, \mathrm{s}, \mathrm{s}, \mathrm{r}$ & $\mathrm{n}, \mathrm{n}, \mathrm{n}, \mathrm{s}$ \\
\hline $0.1 \mathrm{M} \mathrm{NaOH}(6,12,18,24)$ & w.r & w.r \\
\hline
\end{tabular}

Key: $(6,12,18,24)=$ time interval at which the film appearances were examined, that is $6^{\text {th }}$ hour, $12^{\text {th }}$ hour, $18^{\text {th }}$ hour and $24^{\text {th }}$ hour respectively; $\mathrm{n}=$ no effect on film, $\mathrm{w}=$ whitening of film, $\mathrm{s}=$ shrinkage of film and $\mathrm{r}=$ removal of film.

Table 7 shows the chemical resistance of films prepared from FWOAR and CPAR to different solvent media. The alkyd film sample of CPAR was observed to be highly resistant to water and acidic media when compared to that of FWOAR. The poor resistance to acidic media by the alkyd film from FWOAR may be attributed to the high acid value of the alkyd. However, both samples were found to be poorly resistant to alkaline medium. The poor resistance to alkali may be explained on the basis that alkyd resins which is the major ingredient in the paint samples are essentially composed of ester linkage that are susceptible to alkaline hydrolysis (Aigbodion et al., 2001).

\section{Conclusion and Recommendations}

\section{Conclusion}

Results obtained from this study show that the oil and the oil modified alkyd resin synthesized from frywood seeds exhibited good performance characteristics even when compared with the commercially produced resin. This is an indication that the aforementioned seed oil will play some vital roles in various industrial applications such as soap production and formulation of surface coatings. Considering present practices in developing countries like Nigeria where imported oils, such as linseed oil resin, constitute the technical resin used in the coating and its allied industries, substituting these with frywood seed oil and the oil modified alkyd from our locally sourced oil seems to be a step in the right direction.

\section{Recommendations}


It is our wish that further studies be carried out on the formulations of paints and varnishes with their properties using the produced alkyd resin. The active compounds, with their exact structures, present in these alkyd resins can be further identified using the combination of NMR, IR and GC-Mass spectroscopy. It is also our wish that further studies be carried out on alkyd resin production from other locally available vegetable oils to compliment the researched ones for greater availability of raw materials.

\section{REFERENCES}

Abayeh, O.J., Ismail, A. \& Abayeh, O.M. (2011). Quality characteristics of pumpkin (Cucurbita Pepo L) seed oil. Journal of Chemical Society of Nigeria, 36(1): 220 - 223.

Abu-Sayeed, M., Abbas Ali M., Sohel, F.I., Astaq, G.R.M. \& Sarmina, Y.M. (2004). Physico-chemical characteristics of Mesua ferrea seed oil and nutritional composition of its seed and leaves. Bulletin of the Chemical Society of Ethiopia, 18(2): 157-166.

Adewuyi, A. \& Oderinde, R.A. (2014). Fatty acid composition and lipid profile of Diospyros mespiliformis, Albizia lebbeck, and Caesalpinia pulcherrima seed oils from Nigeria. International Journal of Food Science, 283: 614-620.

Aghaie, H., Ilkhani, A.R. and and Sadat, C.S.M. (2010). Utilization of soya bean fatty acid for synthesis of alkyd resin and comparation of properties with other vegetable oils. Journal of Nano Chemical, 18: 142-146.

Aigbodion, A.I., \& Okieimen, F.E. (1996). Kinetics of the preparation of rubber seed oil alkyds. European Polymer Jouranal, 32: 1105-1108.

Aigbodion, A.I., Pillai, C.K.S., Bakare, I.O. \& Yahaya, L.E. (2001). Effect of modification with cardonol-formaldehyde resin on the quality of rubber seed oil and its alkyds as binders in surface coating. Paintindia, 21: 39-42.

Ali, S.I. (1973). Albizia lebbeck (L.) Benth. In: Flora of Pakistan Mimosaceae. University of Karachi, Karachi. p. 73.

ASTM (1979). Test for iodine value of drying oils and their derivatives. In: Annual Book of American Society for Testing and Material Standards, 29: 186-189.

ASTM (1979). Test for saponification value of drying oils, fats and polymerized fatty acids. In: Annual Book of American Society for Testing and Material Standards, 29: 259-261.

ASTM (1994). Standard method for acid value of organic materials. In: Annual Book of American Society for Testing and Material Standards, 6(1): 260-261.

Atta, A.M., El-Ghazawy, R.A. \& El-Saeed, A.M. (2013). Corrosion protective coating based on alkyd resins derived from recycled poly (ethylene terephthalate) waste for carbon steel. International Journal of Electrochemical Science, 8: 5136-5152.

Barbosa, A.D. (2014). Pharmacologically active saponins from the genus Albizia. International Journal of Pharmacy and Pharmaceutical Sciences, 6(11): 32-36.

Barnwal, B.K. \& Sharma, M.P. (2005). Renewable and sustainable energy. Reviews, 9: 363 - 378.

Bobalek, E.G and Chiang, M.T. (1964). Synthesis and properties of some alkyds of more complex carboxyl functionality. Journal of Applied Polymer Science, 8(3): 1147-1168.

Brown, S. (1997). Appendix 1 - List of wood densities for tree species from tropical America, Africa, and Asia. In: Estimating Biomass and Biomass Change of Tropical Forests: A primer. FAO Forestry Papers. p.134.

Christiano, S.D.A., Herlandes, P.T., Joao, B.F. \& Young, R.J. (2006). The fishing rhea: A new food item in the diet of wild greater rheas (Rhea americana, Rheidae, Aves). Revista Brasileira de Ornitologia, 14(3): 285-287

Duke, J.A. (2008). Dr. Duke's Phytochemical and Ethnobotanical Databases - Albizia lebbeck.

El-Hawary, S., El-Fouly, K., Sokkar, N.M.\& Talaat, Z. (2011). A phytochemical profile of Albizia lebbeck (L.) Benth. cultivated in Egypt. Asian Journal of Biochemistry, 6(2): 122-141. 
Esuoso, K.O. \& Odetokun, S.M. (1995). Proximate composition and possible industrial utilization of Blighia sapida seed and seed oil. Sostanze Grasse Press, Sostanze Grasse. pp. 43-54.

Gan, S.N. \& Teo, K.T. (1999). Curing film properties of palm stearin alkyds. Journal of Resin Technology, 28: $283-292$.

Goldsmith, H. A. (1948). Alpha and beta hydroxyls of glycerol in preparation of alkyd resins. Industrial and Engineering Chemistry, 40: $1205-1211$.

Igbo, U.E., Igwe, C.C., Akubueze, E., Ishola, O.R., Odusote, A.O. \& Oyewole, A.O. (2014). Utilisation of beniseed oil for the production of alkyd resin. Journal of Applied Chemistry, 7(5): 104-106.

Ikhuoria, E.U., Aigbodionb, A.I. \& Okieimena, F.E. (2004). Enhancing the quality of alkyd resins using methyl esters of rubber seed oil. Tropical Journal of Pharmaceutical Research, 3(1): 311-317.

Ikhuoria, E.U. \& Okieimen, F.E. (2005). Preparation and characterisation of alkyd resins using crude and refined rubber seed oil. Pakistan Journal of Science and Industrial Research, 48(1): 68-73.

Ikhuoria, E.U., Maliki, M., Okieimen, F.E., Aigbodion, A.I., Obazee, E.O., \& Bakare, I.O. (2007). Synthesis and characterization of chlorinated rubber seed oil alkyd resins. Progress in Organic Coatings, 59: 134-137.

Ikyenge, B.A., Bello, K.A., Adamu, H.M. and Jauro, A. (2015). Physicochemical characterization and performance evaluation of unmodified and montmorillonite (bentone) clay modified alkyd resin from Thevetia nerrifolia seed oils. Global Journal of Advanced Engineering Technologies and Sciences, 2(11): 31-36.

Knothe, G., Phoo, Z.W.M.M. De Castro, M.E.G. \& Razon, L.F. (2014). Fatty acid profile of Albizia lebbeck and Albizia saman seed oils: Presence of coronaric acid. European Journal of Lipid Science and Technology, 34: 176-183.

Lowry, J.B. Prinsen, J.H. \& Burrows, D.M. (1994). Albizia lebbeck: A promising Forage Tree for Semi-arid Regions. In: Gutteridge, R.C. and Shelton, H.M. (Eds.): Forage Tree Legumes in Tropical Agriculture. London. CAB International. p. 23.

MacDonald, P., Edward, R.A. \& Greenhalg, J.F.D. (1994). Animal Nutrition $4^{\text {th }}$ Edn., Longman publishers, London. pp. $22-36$.

Malti, A. (1978). Short course in drying oils. Journal of American Oil Chemical society, 36: 47-52.

Majumder, M.M.U.H. (1990). Studies in the physico-chemical properties of rubber (Hevea brasiliensis) seed oil and identification of different higher fatty acids of the oil and analysis of the seed cake. Science, 14: 31-36.

Mariod, A., Matthaus, B. \& Eichner, K. (2004). Fatty acid, tocopherol and sterol composition as well as oxidative stability of three unusual Sudanese oils. Journal of Food Lipids, 11: 179-189.

Momodu, V.M., Omorogbe, S.O., Ikhuoria, E.U., Obazee, E.O. \& Aigbodion, A.I. (2011). Synthesis and evaluation of performance characteristics of Tetracarpidium conophorum (walnut) seed oil-modified alkyd resin. Researcher, 3(7): 1-4.

Mukhtar, A., Habib, U. and Mukhtar, H. (2007). Fatty acid composition of tobacco seed oil and synthesis of alkyd resin. Chinese Journal of Chemistry, 87: 705-708.

Nzikou, J.M., Kimbonguila, A., Matos, L., Loumouamou, B., Pambou, N.P., Ndangui, C.B. \& Abena, A.A., Silou, T.S.J. \& Desobry, S. (2010). Extraction and characteristics of seed kernel oil from mango (Mangifera indica). Research Journal of Environmental and Earth Sciences, 2(1): 31-35.

Ogbobe, O. (1992). Physico-chemical composition and characteristics of the seed and seed oil of Sclerocarya birrea. Plant Foods for Human Nutrition, 42: 201-206.

Ogunniyi, D.S. \& Odetoye, T.E. (2008). Preparation and evaluation of tobacco seed oil-modified alkyd resins. Bioresource Technology, 99: 1300-1304.

Okolie, P.N., Uaboi-Egbenni, P.O. and Ajekwene, A.E. (2012). Extraction and quality evaluation of sandbox tree seed (Hura crepitan) oil. World Journal of Agricultural Sciences, 8(4): 359-365. 
Oladipo, G.O., Ighodalo C., Eromosele, I.C. \& Folarin, O.M. (2013). Formation and characterization of paint based on alkyd resin derivative of Ximenia americana (wild olive) seed oil. Environment and Natural Resources Research, 3(3): 113-116.

Onukwuli, O.D. \& Igbokwe, P.K. (2008). Production and characterization of castor oil- modified alkyd resins. Journal of Engineering and Applied Sciences, 3: 161-165.

Özcan, M.M. \& Atalay, C. (2006). Determination of seed and oil properties of some poppy (Papaver somniferum L.) varieties. Grasasy Aceites, 57(2): 169-174.

Pagout, C. \& Hautfenne, A. (1987). Standard Methods for the Analysis of oil, fats and derivatives, $7^{\text {th }}$ Edn. Blackwell Scientific publication, Oxford. pp. 143-148.

Ratsch, C. (2004). Enzyklopädie der psychoaktiven Pflanzen, Botanik, Ethnopharmakologie und Anwendungen $7^{\text {th }}$ Edn. AT Verlag. pp. 213-224.

Saad, B., Ling, C.W., Jab, M.S., Lim, B.P., Abdussalam, S.M.A., Wai, W.T. and Saleh, M.I. (2007). Determination of free fatty acids in palm oil samples using non-aqueous flow injection titrimetric method. Food Chemistry, 102: 1407-1414.

Santos, L.M., Coser, E.J., Dullius, E.L. and Einloft, S. (2005). Utilization of palm oil in the alkyd resin synthesis. Faculdade de Quimica - Laboratório de Organometálicos e Resinas.

Singh, S. (2009). Preparation and analysis of alkyd resin from deodourizer distillate. Journal of Scientific and Industrial Research, 68 : 807-811.

Zeno, W., Jones, F.N. \& Pappas, S.P. (1999). Organic Coatings, Science and Technology $2^{\text {nd }}$ Edition. Wiley Interscience, New York. pp. 34-56.

Zimba, N., Wren, S. \& Stucki, A. (2005). Three major tree nut oils of southern central Africa: their uses and future as commercial base oils. International Journal of Aromatherapy, 15: 177-182. 